\title{
A infância perdida: conflito militar de 07 de junho de 1998 na Guiné-Bissau
}

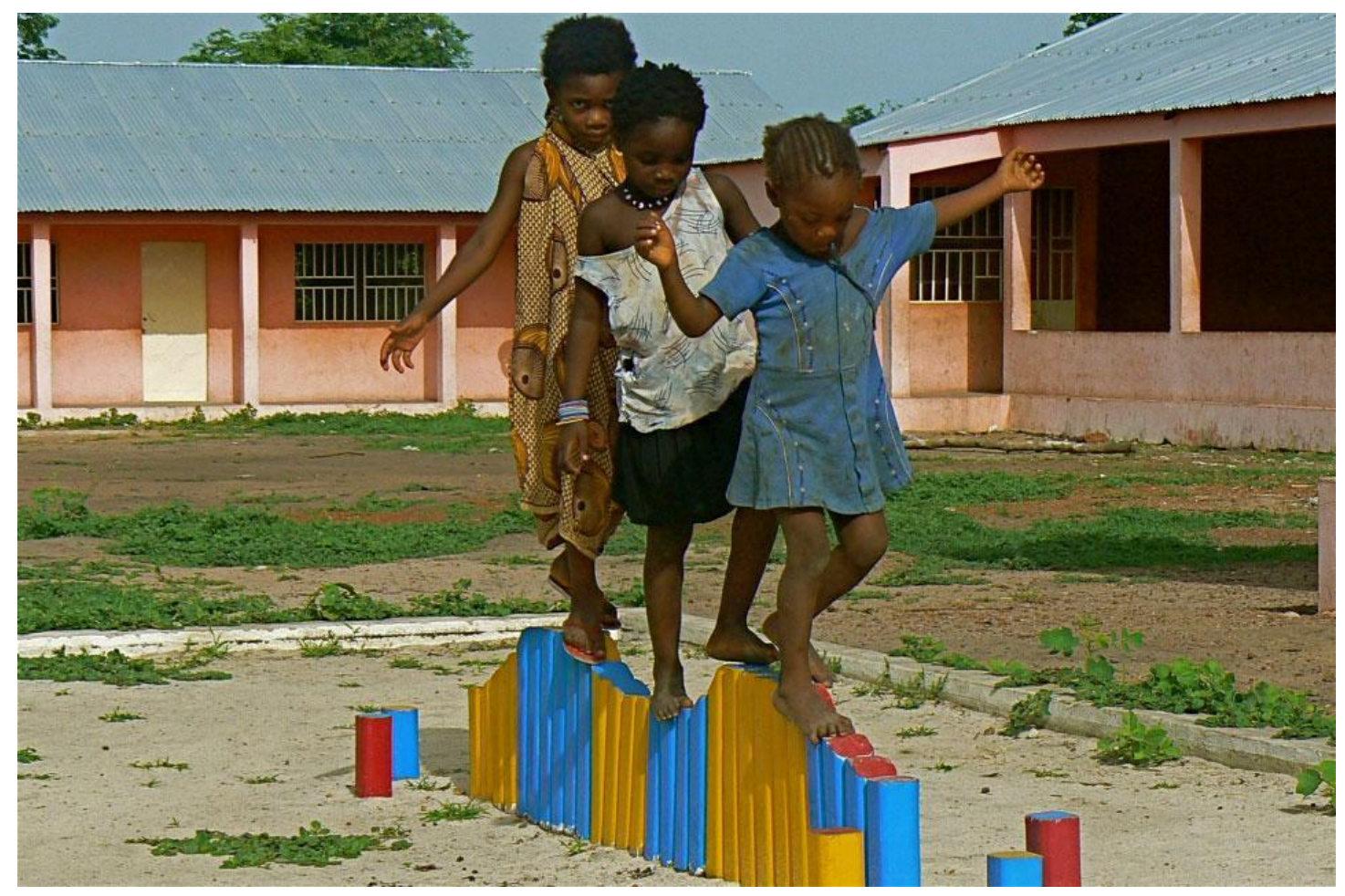

RESUMO: A infância perdida é nome que dei a minha má experiência na infância em Guiné-Bissau. Tive uma infância no período da guerra e o período pós-guerra não foi diferente. Uma experiência que deixou marcas cicatrizadas dentro de mim, na minha alma e no meu espírito. Que Deus tenha a alma dos meus colegas e todos que perderam suas vidas durante o conflito político militar de mil e novecentos e noventa e oito entre o falecido e antigo presidente da república, João Bernardo Vieira (Nino Vieira) e o falecido general Ansumane Mane (Brigbarak).

PALAVRAS-CHAVE: infância perdida; conflito militar; Guiné-Bissau.

\footnotetext{
${ }_{1}^{1}$ Mestrando em Humanidades pelo Programa da Pós-graduação da Universidade da Integração Internacional da Lusofonia Afro-Brasileira - UNILAB. E-mail: adilsonvictoroliveira@gmail.com
} 


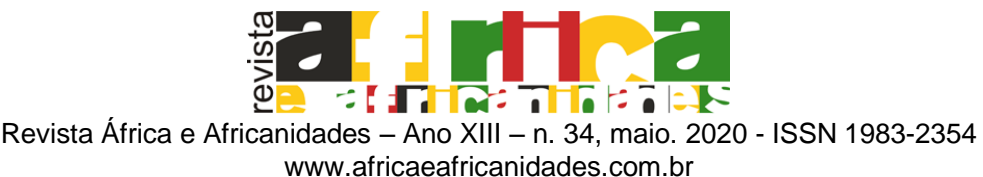

www.africaeafricanidades.com.br

\section{Introdução}

O período pós-colonial com a criação da primeira república que se desabou com golpe de estado de 14 de novembro de 1980, na qual general João Bernardo Vieira então primeiro ministro derrubou o presidente da república Luís Cabral. A partir daí começa a segunda república na qual se suspendeu a constituição da república e criou um governo de base militar a partir de conselho da revolução. O país passou por vários momentos difíceis desde que se tornou independente de Portugal em 24 de setembro de 1973 por meio de uma guerra armada que durou onze anos, liderado pelo agrônomo Amílcar Lopes Cabral que acabou sendo assassinado um ano antes da proclamação da independência.

No entanto, a difícil situação que se viu a quando da formação da primeira república influenciou negativamente a estrutura estatal do país, fazendo e trazendo assim desconforto e desconfiança entre as lideranças do país e em consequência disso, houve várias tentativas de golpes e centenas assassinatos de civis, quadros técnicos que voltavam ao país de estudos nos países socialistas, dos militares. E isso tem ocorrido longo de todo esse período de 1973 a 1998. Contudo, as perseguições que se faz sentir no meio da população não só provocou exilo de muitos políticos e familiares para exterior, mas também teve consequência de fuga de quadros técnicos do país. Para isso, minha esperança de vida, meu futuro tornou-se confuso na medida que, nasci numa sociedade que não olha criança como flor e esperança do futuro. Hoje consigo entender o mal que a instabilidade que se viveu e vive no meu país faz em mim sendo um jovem de jovem país na costa da África ocidental da língua oficial portuguesa conhecida como Guiné-Bissau.

Neste relato de experiência de vida buscarei relatar história da minha infância em relação ao conflito político e militar de sete de junho de mil e novecentos e noventa e oito em Guiné-Bissau um país situado na costa da África ocidental e faz fronteiras com república do Senegal e da Guiné Conacri, um pais com mais de 90 ilhas. Destacarei as principais causas e efeitos da guerra na minha vida enquanto criança na altura e em seguida, explicar porque que a minha infância é perdida. E responder a mim mesma as questões que não param de mim perseguir: será possível uma criança ter boa infância num país que se encontra em conflito armado? Quais as consequências da guerra na vida de uma criança? No final de tudo, quem venceu a guerra? Desde já antes de responder essas questões, manifesto minha limitação em encontrar fontes em relação a esse assunto, por exemplo, imagens da guerra, depoimentos dos jovens que eram crianças na época. Essas dificuldades têm a ver com a falta de materiais disponível como jornais, revistas, ou seja, durante a guerra de sete de junho de 1998, as forças envolvidas suspenderam as imprensas e outros meios que facilitavam a comunicação oral ou escrita. Hoje as dificuldades de encontrar fontes são maiores devido essas situações. Por isso, irei tentar apresentar aqui por meio da minha narrativa, minha experiência em relação ao conflito político e militar de mil e novecentos e noventa e oito em Guiné-Bissau enquanto criança no meu de vida e morte.

Eu considero minha vida de muita turbulenta por motivos que mostram meu percurso e da nossa família antes da guerra. Tínhamos uma vida normal em 


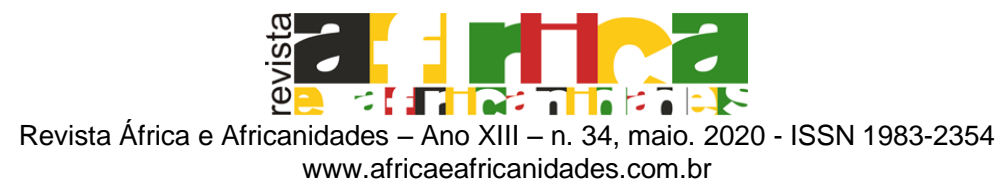

termos da educação, saúde, em termos financeiros. Já no período pós-guerra só lembro da minha existência passada antes da guerra e, ela está cheia de magoa e dor, cheia de lembranças de sangue dos meus colegas, vizinhos e demais pessoas que perderam suas vidas durante a guerra. Percebi que a guerra não conhece e não respeita criança. A guerra não respeita idosos, gravidas, deficientes. A guerra não respeita animais, não respeita os bens materiais $e$ imateriais. A guerra só tem único objetivo, matar, paralisar e destruir tudo que uma criança pode sonhar. Minha infância foi assim roubada pelos políticos e militares porque são eles que fizeram a guerra, são eles que nos torturaram e nos destruíram juntamente com nossos sonhos. Hoje, vinte e dois anos após a guerra de 1998, meu país está pior ainda e com tendências para piorar ainda mais.

As crianças que hoje estão lá, perdendo suas infâncias, que passam fome, doenças, violências corporais sem um Estado para lhe defender seus direitos. Pais sem condições para suprir suas necessidades diárias, tudo isso, pode ser visto como consequência da guerra que destruturou o país em 1998-1999.

\section{Madrugada inesquecível}

Madrugada de nove ${ }^{2}$ de junho de 1998, eu estava deitado na minha cama, no meu quarto, na casa que meu tio deu por empréstimo ao meu pai. Um quarto que compartilhava com meu irmão mais velho que, neste dia se encontrava no interior de Bissau, um quarto que as vezes servia de despensa, lugar onde minha tia guardava alguns garrafões de vinho de caju. Foi neste quarto que eu estudava, dançava aquelas músicas que gostava, como "djugudé djugudé nmas bá ta bua3", "disco dancer de Djimmy", "katchur ta missa só ku um pé"5, são minhas músicas preferidas na época. Minha tia chegava de mandar calar e dormir, pois a casa não tinha teto de modo que minha voz passava das paredes, passava nas portas e janelas e atingia os quartos próximos de mim. Foi neste quarto que por volta de cinco horas de madrugada do dia nove de junho de 1998 fui acordado com grito da minha tia que pedia para vestir roupa e que íamos sair de casa imediatamente.

\footnotetext{
2 O conflito militar que começou no dia sete de junho de mil novecentos e noventa e oito na Guiné-Bissau entre as forças governamental liderado pelo ex-falecido presidente general João Bernardo Vieira (também era conhecido com alguns nomes no período da guerra de libertação contra o governo de Portugal como, Nino Vieira e Kabi Na Fantchagna) e as forças denominado de Junta Militar liderado pelo ex-chefe de estado maior general das forças armadas Ansumane Mané. Coloquei nove de junho, porque foi o dia que intensificou combate fazendo com que a maioria dos cidadãos se refugiassem para interior ou exterior de país.

3 Música cantada em todas as cidades, mas não se sabe a autoria, e ela é uma ironia. Traduzida a letra para português significa "voar mais que um abutre, ou voar mais rápido que um abutre". ${ }^{4}$ É um filme de drama musical da Índia cujo tema é "Disco Dancer" lançado no ano 1982 pela Bolywood e é da autoria de Rahi Masoom e, foi dirigido pelo Babbar Subhash (Jimmy). É um filme muito conhecido e que todas as crianças naquela época gostavam de assistir, principalmente no bairro que morávamos.

${ }_{5}^{5}$ Música de Patcheco de Gumbe, um músico guineense já falecido. A música é de tipo Gumbé ou Mgumbé, música tradicional guineense, ou seja, umas das mais tocadas no país.
} 


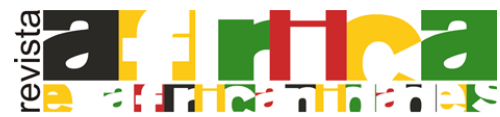

Revista África e Africanidades - Ano XIII - n. 34, maio. 2020 - ISSN 1983-2354

www. africaeafricanidades.com.br

Acordado meio tonto de sono, sem calçado nos pés fui correr para sala querendo saber mais detalhes, mas a tia respondia que não tinha explicação, a única explicação era de arrumar e sair da cidade de Bissau. Minha prima Quinta Mancabu que nessa época só tinha quatro anos de idade, chorava querendo braços da minha tia que é a sua mãe, mas a tia estava a arrumar algumas roupas e mantimentos para viagem. Quinta, Quinta venha para meu quarto, vamos brincar de ndulé-ndulé ${ }^{6}$, mentu ${ }^{7}$ ou dar-dar ${ }^{8}$ dizia eu. Na infância eu e minha irmãzinha gostávamos de brincar com nossas colegas vizinhas. Tínhamos umas hortas de caju atrás da casa é ali que passávamos maior parte de tempo brincando com colegas os jogos por exemplo mé-mé ${ }^{9}$, cabra-cega ${ }^{10}$, siló-diata ${ }^{11}$, surumba-surumba ${ }^{12}$ e outros, mas só era possível brincar depois de terminar de resolver TPC (trabalho para casa, ou seja, em Guiné os professores/as sempre dão trabalhos "exercício" em todos finais das aulas para irmos resolver e entregar na aula seguinte). Aí, minha irmãzinha respondeu, vamos jogar, vamos jogar! Mas, meu pai respondeu com uma voz de autoridade, uma voz que sempre usava para chamar atenção quando algo estava de errado entre nós em casa. Aí gritou, ninguém brinca hoje, venham todos para sala vamos conversar, estamos sem tempo.

O tio que eu chamava de pai, mas, na verdade, era irmão do meu pai e pela tradição da nossa etnia ele tem por direito tomar primogênito do seu irmão para criar, e eu estava lá nessa condição, pois era primeiro filho do meu pai. Ele (meu tio) era pai e fazia tudo de pai, de modo que não sabia de outro pai além dele. Depois que todo mundo se reuniu na sala, ele falou para nós que a cidade estava numa crise, estava tendo guerra no centro da cidade e que devíamos partir logo

\footnotetext{
${ }^{6}$ É um jogo que os mais velhos faziam com as crianças, na qual colocavam todo mundo no chão com pernas estendidas e começava a jogar cantando e correndo a mão nas pernas das crianças até terminar a música na perna de umas das participantes e esse aí perde, eu e minha irmãzinha gostávamos de brincar de ndulé-ndulé.

7 É nome de um jogo entre duas ou mais pessoas, na qual uma toca na outra e corre, em seguida a outra sai correndo para tornar-se. Tem um significado no ato de despedida principalmente entre pessoas da mesma geração.

8 Dar-Dar é nome dado a um jogo na qual, o mais velho organizava as crianças e começava jogo, ou seja, dizia: dar-dar, as crianças respondiam dar, em seguida ele respondia mandar buscar, aí chamava nome de um objeto distante, aí todo mundo saia correndo para pegar e retornar a ele/a. quem conseguir chegar primeira ganhava primeira posição no jogo. Aí prosseguia o jogo até chegar no último perdedor/a.

${ }^{9}$ Mé-mé também é um jogo comum entre as crianças das mesmas gerações em Guiné-Bissau. Se cantava uma música enquanto batiam as mãos umas nas outras cantando: mé-mé (8x), tatimbolota (8x), tam-ta ra-ra (8x) ... se um dos participantes errar sai do jogo.

${ }_{10}$ Cabra-cega é um tipo de jogo de círculo, as crianças se formam em círculo e em seguida colocam um lenço vendado os olhos de quem estará no meio. Ai esta tenta agarrar as outras envolvidas no jogo e, assim que adivinhar e conseguir agarrar sai do meio e entra aquela que foi agarrada.

${ }^{11} \mathrm{Na}$ Guiné-Bissau o nome siló-diata é nome de ônibus e, para brincadeira das crianças usavase cordas ou linha ajeitada em forma de poder levar passageiros. Aí tinha motorista e cobrador, enquanto os passageiros ficavam no meio. Ai saia correndo por todo canto, gritando de alegria. 12 Surumba-surumba é um jogo em quadradinho no chão. Normalmente joga-se oito pessoas. Quadro dentro os quadradinhos e quatro de lado de fora. Assim, as pessoas do lado de fora tentam tocar nelas, assim sucessivamente.
} 
antes que chegasse a nós. Sem mais detalhe pediu para sairmos da casa em direção à Ponta Rocha ${ }^{13}$ uma cidade fora da capital Bissau.

Fui correr para galinheiro onde a galinha que a tia Rosa ${ }^{14}$ mãe de Paú ${ }^{15}$ me deu para criação, pois que falcões, raposas e as vezes pessoas roubavam as galinhas na sua casa. As vezes também acontecia que as galinhas morriam por causa do peste. Foi nesta perspectiva que ela me deu uma para criar. Recebi a galinha e após três meses a galinha deitou nove ovos e teve oito pintainhos. A tia Rosa recebeu seis para vender e me deu dois pintainhos. Um tempo depois a galinha teve mais nove pintainhos e ela me deu quatro. A nossa casa estava cheia de galinhas até a madrugada do dia nove de junho.

Cheguei no galinheiro peguei as galinhas, mas o tio proibiu porque não ia conseguir nos levar com as galinhas, nem os porcos que a tia criava no chiqueiro atrás da casa. Na verdade, os porcos até estavam a grunhir achavam que a tia estava a levar a comida para eles. A tia não teve tempo de organizar as garrafinhas de vinho "mécó ${ }^{16}$ " de caju nem fazer peixes para vender "bafatório/ kumpu boka" ${ }^{17 " ~ p o r q u e ~ o ~ t i o ~ e s t a v a ~ n o s ~ a p r e s s a r ~ p a r a ~ s a i r ~ d a ~ c a s a ~ e ~}$ dizia ele, o quanto mais aproveitar o tempo de madrugada mais seguro seria para nos viajar calmamente.

Eu estava muito feliz para sair de casa, pois nunca a gente tinha feito viagem assim em família, seria uma boa oportunidade para brincarmos com outras crianças. Perguntei o pai se tinha criança para onde a gente ia, e ele não respondia, mas eu tinha certeza que sim, porque havia crianças por todo canto de Bissau. Até pensava que agente ia sair para casa da minha tia irmãzinha do pai no outro bairro arredor de Bissau. Fui pegar na bola e sapato de treino falei para minha irmãzinha pegar seus jogos pois lá para onde íamos tinha muitas crianças e íamos querer jogar e, ela foi pegar todos os jogos dela.

${ }^{13}$ É uma secção de sector de Safim, região de Biombo. É a cidade mais próxima de capital Bissau. É a cidade onde pais dos meus pais nasceram. É lá que reside maior parte da família do meu pai.

${ }^{14}$ Era uma senhora que morava numa rua seguir a nossa. Meu pai (tio) me dizia para Ihe chamar de tia e eu só chamava de tia. Ela gostava de criar galinhas, porcos, cabras e patos, mas na rua morava muitos jovens que roubavam suas crias, por isso, ela me deu uma galinha para criar.

15 É um nome utilizado na étnica Mancanhes ou Brame que significa menino. O termo se designa todos os meninos e com tempo, muitas outras etnias inclusive Mancanhes passam a usá-la como nome próprio.

16 É um termo comum entre as vendedoras de vinho de caju ou vinho palmo e os consumidores. Esse nome significa meio copo ou vinho até meia garrafa. É uma medida que permitia os consumidores economizarem dinheiro e tempo. Em termos de custos também era melhor.

$17 \mathrm{Na}$ Guiné-Bissau é muito comum entre as pessoas que bebem qualquer tipo de vinho beber acompanhado de algum tipo de molho de peixe ou carne assado. Ou seja, bafatório, kanfurbat e kumpu boka têm o mesmo significado, são temperos que se faz com cacre (é um tipo de marisco, família de caranguejo), peixe ou carne para ajudar a pessoa que bebe algum tipo de bebida alcoólica a não ficar bêbado rápido. 


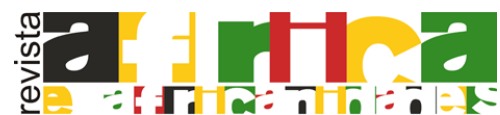

Revista África e Africanidades - Ano XIII - n. 34, maio. 2020 - ISSN 1983-2354

www.africaeafricanidades.com.br

Pedi o pai para me levar ao banheiro. Nosso banheiro estava de lado de fora da casa, no quintal da casa, eu sozinho não ousava ir, tinha medo do kankuram ${ }^{18} \mathrm{e}$ sapa-kabeça ${ }^{19}$. O pai sempre falava que kankuram devorava crianças, principalmente crianças desobedientes que não escutavam os mais velhos. Enquanto que sapa-kabeça são os mercadores que procuravam cabeças e órgãos das crianças para vender no estrangeiro, então, a criança não podia sair sozinha da casa era perigosa. Quando o pai abriu a porta eu vi nas casas vizinhas e na estrada multidões de pessoas carregadas com suas malas, com crianças nos braços e nos ombros outras nas costas indo em direção a feira de mancara. Falei para o pai que a gente devia ir parece que todo o mundo estava a ir e nós não íamos ter espaço na toca-toca ${ }^{20}$. No banheiro sente um som, um som que parecia de trombeta, parecia motor de carro ou vento na praia de Bambaia $^{21}$ no sul do pais. Foi nessa altura que o pai entrou no banheiro e me arrebatou nos braços correndo para dentro da casa. Espanto do jeito que o pai estava a comportar assim comigo, comecei a chorar, pois o pai estava muito diferente. Parecia umas vezes quando ele bebia e ficava meio chato conosco em casa, mas era muito cedo ele não bebeu. E eu exclamei! Afinal o que está acontecendo em casa e nas vizinhanças?

Dentro da casa o pai apressava todo mundo para sair. Foi nessa altura, por volta de seis horas de manhã que saímos da casa em direção a feira de mancara. Eu não consegui levar minhas galinhas, nem a bola. Minha prima também não levou os jogos e a tia não levou seus porcos só algumas roupas e mantimentos. Nós, eu e a minha irmã nos braços do pai brincávamos, gritávamos de alegria, um batia no outro de brincadeira. Estávamos muito felizes, pois estávamos a sair de casa todos juntos.

Andamos até o sol chegar onde chegava no horário de intervalo (recreio) na escola. Na verdade, na escola de Nicolau Mancabo ${ }^{22}$ a gente saia intervalo umas

\footnotetext{
$18 \mathrm{Na}$ tradição de algumas etnias na Guiné-Bissau, kankuram rigorosamente falando, é nome de um ser que acompanha os meninos circuncisados durante seus processos de iniciação no mato. Este ser no interior da capital Bissau é muito perigoso, pois as mulheres, os homens que ainda não passaram por esse processo de iniciação não podem cruzar caminho com ele. Mas, diferentemente daquilo que acontece na capital Bissau em que alguns jovens vestem das folhos e caules de plantas dançando com as mulheres e jovens durante o período de iniciação na capital. É importante aqui frisar que, kankuram de capital e do interior são diferentes, muitas vezes as pessoas que vestem este kankuram de capital quando forem para o interior não ouçam sair na rua quando o verdadeiro saiu. Por isso, tendo limitações não tenho como explicar claramente como é o kankuram do interior.

${ }_{19} \mathrm{Em}$ algum momento na Guiné-Bissau fala-se de alguns cidadãos estrangeiros que raptavam crianças para venderem seus órgãos. Esta informação foi fortemente difundida nas rádios do país e até que os estrangeiros se sentirem suas vidas ameaçadas. Neste período os pais não deixavam as crianças saírem sozinhas, pois tinham medo de alguém as rapte. $E$ todas as crianças sabiam dessa história, por isso, senti medo de ir ao banheiro sozinho sem acompanhamento do meu pai.

20 São meios de transportes urbanos. São eles que fazem ligações entre diferentes bairros da cidade de Bissau.

${ }^{21}$ Uma tabanca no sul do país, região de Quinara, sector de Empada, secção de Darsalam. Bambaia tinha uma das melhores praias de da província sul.

22 Era uma escola privada onde íamos de banco (cadeira). Nicolau Mancabo era dono e professor na sua escola. Foi ali que estudei até terceiro ano da escolaridade.
} 


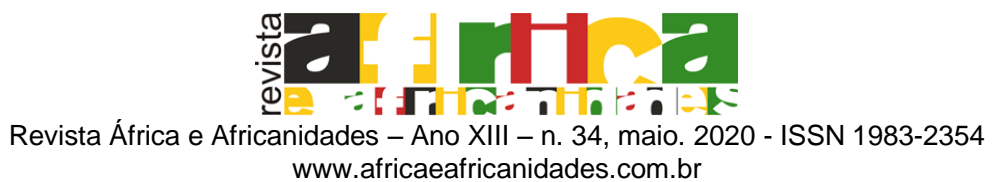

dez horas de manhã. Foi exatamente nesse horário que chegamos à Ponta Rocha. Era a cidade dos meus avôs. A gente sempre ia para lá nos períodos da campanha de caju. O pai tinha uma horta de caju que a tia ia controlar nos períodos da campanha porque o pai não tinha tempo passava semana no quartel paiol no bairro de Brá. O pai era militar naquela época e sempre que ia para quartel as vezes me levava nos ombros. Eu passava tempo com os soldados. Eles adoravam brincar com o filho do comandante e eu os amava.

Em Ponta Rocha a avó estava já arrumar para fugir da cidade. Ela queria ir para $C^{23}$ na região de Cacheu, pois ali tínhamos mais terrenos e mais família e era mais segura pois estava distante da capital Bissau.

Eu, na verdade estava a dormir nos braços do pai, acordei e escutei o pai explicar para avó de que estava tendo guerra entre um grupo de militares contra a presidência da república. Para isso, era necessário sair da cidade urgentemente porque estavam a lançar canhões e balas por todo lado e que podia atingir as crianças a qualquer momento. Minha avó começou a chorar, a tia também e algumas vizinhas parentes também começaram a chegar e todo mundo chorando. Eu falei para o pai de que queria ver a guerra, mas o pai não me respondia afinal ele tinha uma intenção. Pediu avó para fazer almoço com urgência porque não era seguro ficar em casa, seria melhor irmos para Có. Quando sai na rua, vi centenas de milhões de pessoas com suas crianças e roupas, outros de carro, de moto, da bicicleta e outros andando passando em frente a nossa casa (casa da avó) indo em direção à Corda de Safim ${ }^{24}$ alguns choravam de desespero, por verem já muitas pessoas mortas por balas e também por terem deixados suas casas, suas pertenças, seus sonhos fugindo da guerra. Naquela altura algumas pessoas já começam a falar de números de mortos, pessoas evacuadas para hospitais, cadáveres nas pistas, roubos e arrombamento das lojas, eu em casa ouvindo tudo pela estrada e na rádio que avó tinha em casa.

De repente começaram a chegar gente na nossa casa. Gente que não conhecíamos, mas pediram para Ihes deixarem passar a noite e fazer comida para a família. Naquele dia estiveram mais de quinhentas pessoas em casa. E eu estava muito feliz pois tinha muitos dos meus colegas de idade e achava que a gente ia poder brincar todos os dias juntos.

No dia seguinte pela madrugada começou grito de choro. Tinha caído obus de canhão na cidade e muitas pessoas morreram. Foi momento mais difícil na altura. Naquele momento todo mundo arrumando para fugir de novo, não tinha segurança para ninguém. Fui ver o pai, afinal ele foi levado para quartel. Os seus colegas vieram durante a noite e obrigaram-no a ir para quartel, pois estavam a precisar dele. Saímos sem ele, fomos para Safim e no período da tarde ele veio com o carro e nos levou para Có.

\footnotetext{
${ }^{23}$ Secção de Có pertencente à sector de Bula região de Cacheu, é lá onde reside maior número da nossa etnia Mancanhes ou Brames.

${ }^{24}$ Chamamos de corda de Safim porque tem um posto policial na qual controlavam todas as entradas e saídas das pessoas e mercadorias para dentro e fora da capital Bissau.
} 


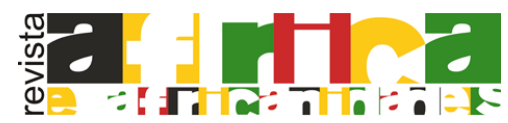

Revista África e Africanidades - Ano XIII - n. 34, maio. 2020 - ISSN 1983-2354

www.africaeafricanidades.com.br

Parece até calmo nos primeiros dias da nossa chegada em Có. Mas, de repente começou-se a ouvir barulho de balas e centenas de pessoas que eram trazidas de Bissau para hospital de Bula e Có, pessoas feridas no combate com as forças governamental. As zonas de Bula e Có estavam a ser controladas pelas forças da Junta Militar e isso permitia trazerem seus soldados feridos na guerra em Bissau.

Ah sim, agora sei o que é a guerra. A guerra é o sofrimento, perda de paz, número de mortos, falta da comida, doenças de todo tipo. Tinha muita gente em casa que começou a faltar a comida. Muitas vezes avó deixava comida para nós, foi ali que surgiu a ideia de irmos para sul do país, ali era celeiro em termos de arroz, talvez estaríamos melhor e teríamos a comida para toda família e aqueles que vieram pedir abrigo em nossa casa. Uma semana depois fomos para sul do país, meu pai tinha uma casa e também tem horta de caju, banana, laranja, limão, ananás. Também lavrava inhame, manfafa, amendoim, feijão, mandioca, tifa, batata-doce, sucur-cala e outros. Foi ali que pela primeira vez tive oportunidade de ir para praia com meus irmãos e colegas, como ilustra a imagem em seguida.

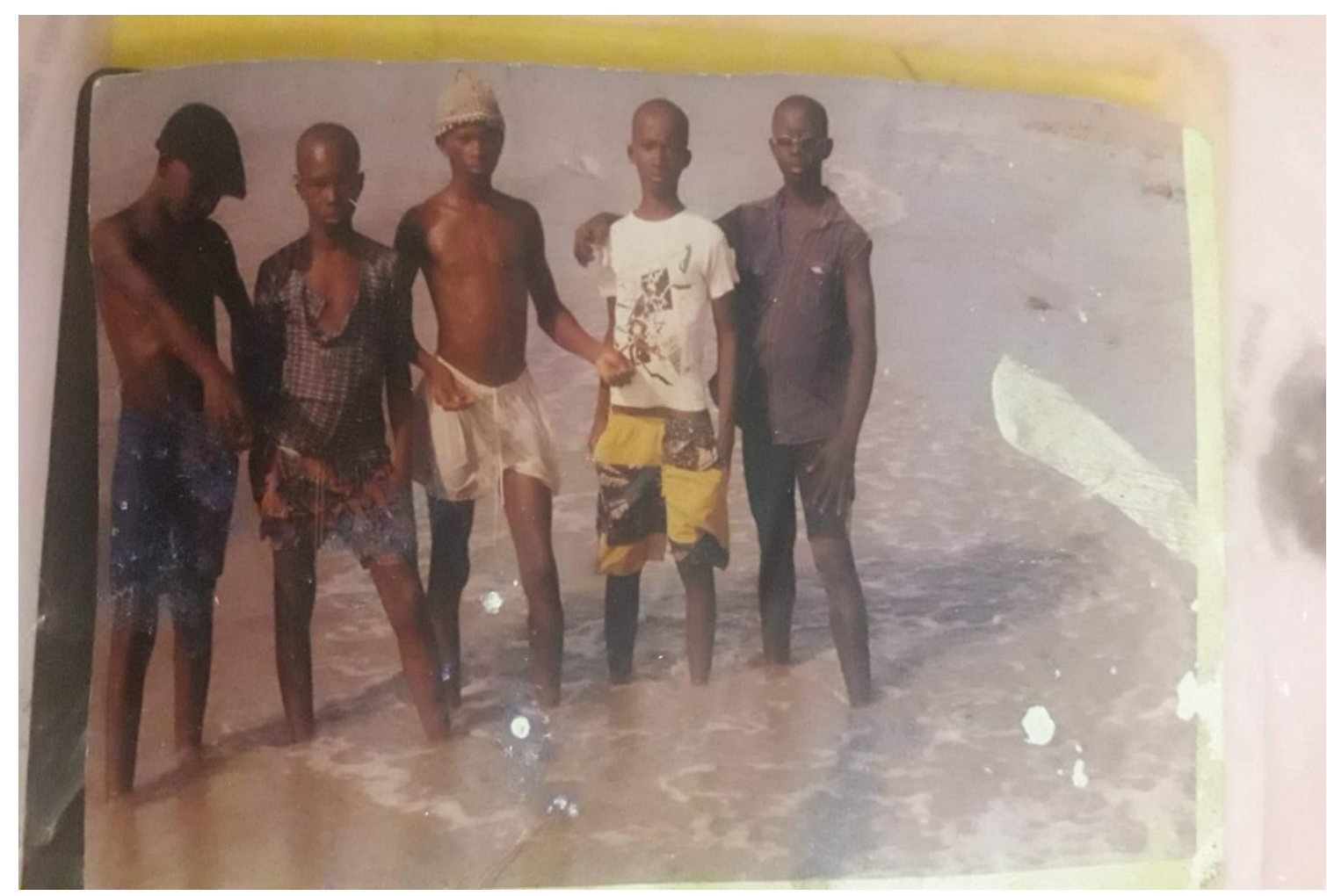

Fg. Essa foto foi tirada no dia primeiro de maio de $1999{ }^{25}$ na praia de Bambaia no sul do país. Eu de bermuda branco no meio dos quatro colegas. E, nossos irmãos mais velhos estavam lá para festejar primeiro de maio dia dos trabalhadores. Na verdade, não lembrávamos que estávamos no período da guerra, a única coisa que sabíamos era brincar. No sul do país não houve muito confronto entre as duas forças em guerra. Em algumas vezes houve pânico, as

25 Foi neste mês que acabou a guerra em Bissau. Uma guerra cuja a junta militar anuncia sua vitória. E quem anunciará a vitória das crianças? 


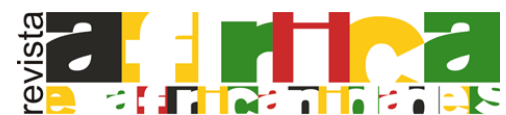

Revista África e Africanidades - Ano XIII - n. 34, maio. 2020 - ISSN 1983-2354

www.africaeafricanidades.com.br

pessoas fugiram para tarrafe/mangal, mas depois a situação foi controlada pela força da Junta Militar.

O conflito político e militar de sete de junho de 1998 foi uma violência, uma história de mortes de crianças, jovens, gravidas, adultos e idosos.

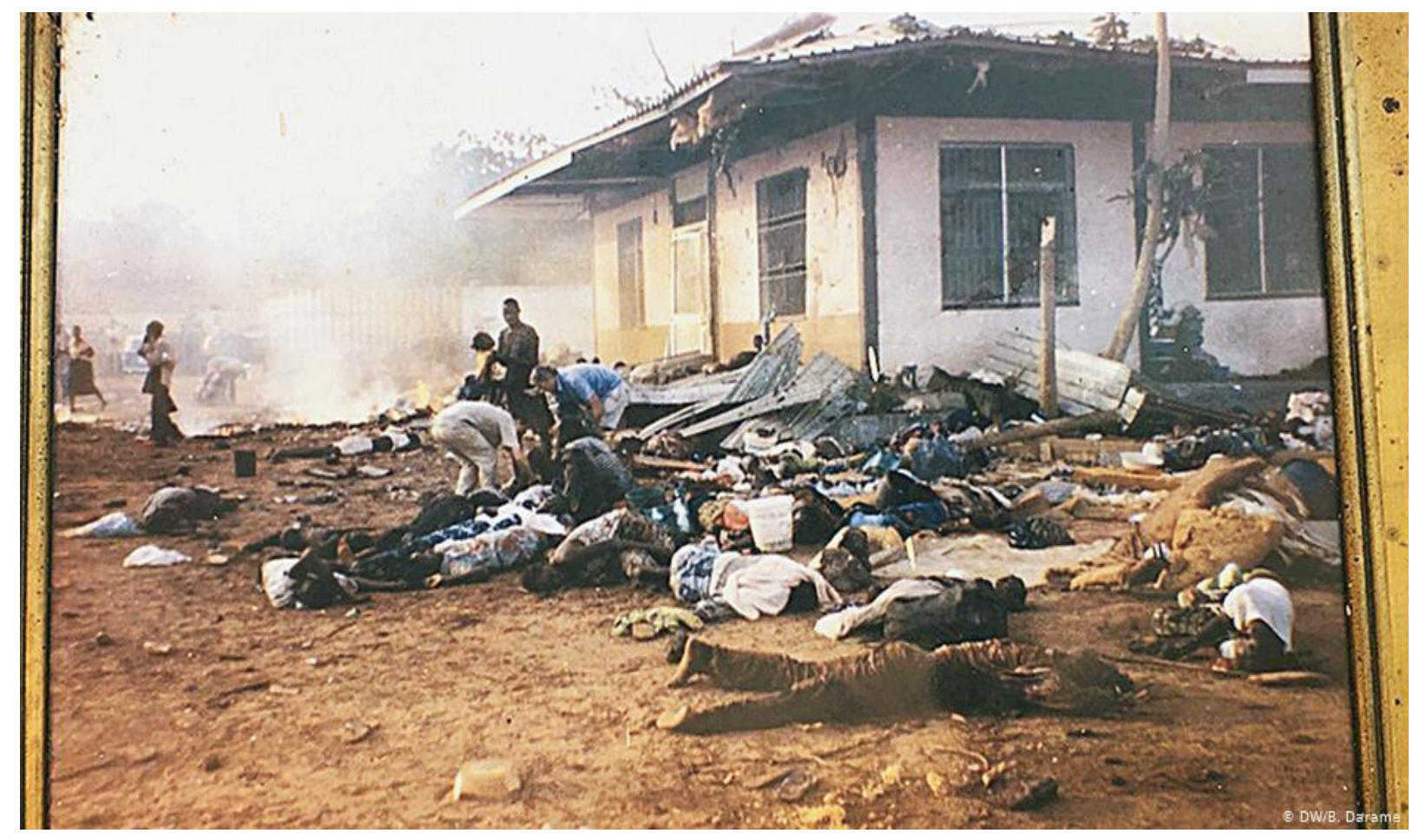

Fg. A imagem retirada da Agencia de Notícia da Guiné (ANG) ${ }^{26}$ mostra corpos de centenas de pessoas que tinham refugiadas no centro católica "Centro de Instrução Formação Artesanal e Profissional, Cifap/Bissau". A bala de canhão caiu sobre o centro e teve centenas de mortes, entre eles crianças e mães gravidas, logo nos primeiros dias do conflito militar de sete de junho de mil e novecentos e nove e oito.

Hoje sentimos que nossa infância foi fortemente violentada pela guerra. A guerra que não mudou nada nas estruturas políticas elitizada. Uma guerra de onze meses que serviu simplesmente para derramar sangue de crianças. Hoje temos crianças mutiladas, crianças que perderam mãos, olho direto ou esquerdo. Crianças que não andam, crianças que hoje não podem levantar colher à boca, tem que ter baba para cuidar. Crianças de ontem e que hoje são jovens paralíticos sem nenhuma indemnização para família.

Meu país Guiné-Bissau situado na costa na África ocidental, um pequeno pedaço da terra, com cerca de $36.125 \mathrm{~km}$. um país cheia de riquezas naturais, um país

26 Gostava de trazer outras fontes de jornais da época para ilustrar neste artigo, mas infelizmente não consegui devido à falta de materiais disponível. É importante realçar que com o conflito político militar de 1998 as imprensas públicas e privadas foram invadidas e deixaram de emitir suas atividades. Nos dias atuais torna-se difícil encontrar fontes nestes órgãos de comunicação devido a essa situação. Em alguns casos se encontram relatos da situação da guerra de 1998, mas sem grandes detalhes a respeito. 


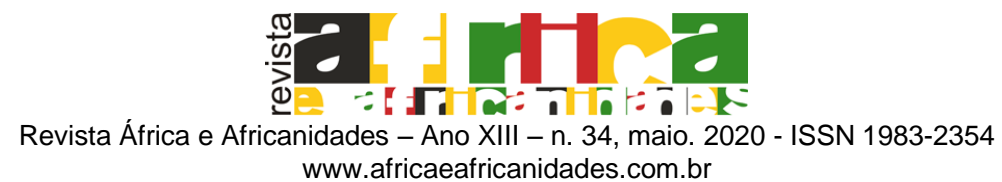

com riquezas étnicas extraordinária, um país na qual as religiões endógenas, religiões cristãs e muçulmanas se convivem tanto nos momentos sagrados assim como nas festas. Um país na qual ninguém se vive por pertencer a um grupo de pessoas, etnia ou religião, mas sim por ser guineense e vive na sua guineendade.

Minha memória da guerra sete de junho de mil novecentos de noventa e oito que durou onze meses sempre foi de muita dor. Perdi minhas galinhas, minhas roupas, sapatos, bolas, cadernos, canetas, lápis de cor para desenho. Perdi meus colegas, minha aula, novela carrossel que assistíamos a dezanove horas. Perdi passeio com colegas na rua da casa do Maikel. Perdi as danças das rapaziadas que bebiam vinho em casa e dançavam entre eles. Perdi brincadeira com minha irmã e meus colegas.

O período pós-guerra, os pais já não deixavam as crianças saírem para brincar como era antes da guerra. Tudo mudou, até minha escola onde estudava mudou, ficou mais longe da minha casa e por isso, meu pai me mudou da escola. O mais triste é que quando voltamos da guerra havíamos pensado que os nossos vizinhos iam se voltar de seguida, mas infelizmente, até hoje não voltaram, alguns morreram. Uns morreram da bala e outros da doença e fome e alguns decidiram não voltar para a capital, com medo de voltar a acontecer guerra.

Quem venceu a guerra? Torna difícil responder essa questão, pois os vencedores da guerra Ansumane Mané e João Bernardo Vieira (Nino). Fizeram guerra e não morreram, seus filhos não morreram e acima de tudo eram mais protegidos. Eles que foram protagonistas da guerra viveram com suas famílias, suas posições sociais, suas vidas financeiras e nós pobres, perdedores, na altura voltamos da guerra pior ainda do que antes. Sem casas para morar, sem condições financeiras e com mais prejuízo. Diz-se que, o João Bernardo Vieira perdeu a guerra. Ele foi-se exilar em Portugal, enquanto que o brigadeiro general Ansumane Mane continua chefiando as forças armadas revolucionário do povo em Guiné-Bissau até ao seu assassinato em 30 de novembro de 2000.

Fg. Foto tirada durante celebração de primeiro acordo de paz entre os dois protagonistas do conflito político e militar em Guiné-Bissau. Do lado esquerdo é o general João Bernardo Vieira o então presidente e a direita é o brigadeiro general Ansumane Mané.

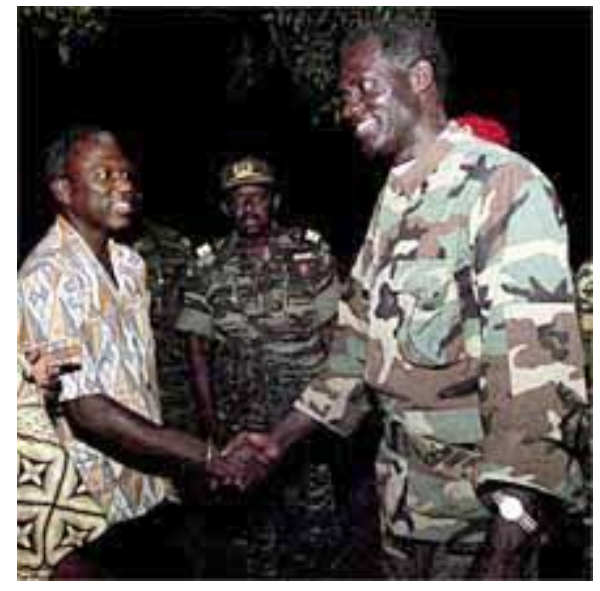




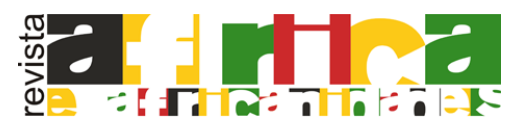

Revista África e Africanidades - Ano XIII - n. 34, maio. 2020 - ISSN 1983-2354

www. africaeafricanidades.com.br

A guerra roubou tudo de nós crianças, perdemos oportunidade de viver num país de paz, amor e sem fome. Desde 1998 meu país nunca mais voltou a ser um país de estabilidade, sempre e constantemente golpes, assassinatos, espancamentos, perseguições políticas.

No seu livro intitulado Guiné: 24 anos de independência 1974-1998, o ex portavoz do comando Supremo de Junta Militar, o coronel Zamora Induta afirma que, após a derrota do General João Bernardo Vieira, "quarenta e outo horas passadas, o Comando Supremo da Junta Militar exige a Nino Vieira que formule a sua rendição, para que se possa oficializar o seu acolhimento na embaixada de Portugal" (INDUTA, 2001, p. 183). E este por sua vez, renunciou das suas funções como consta na nota a seguir.

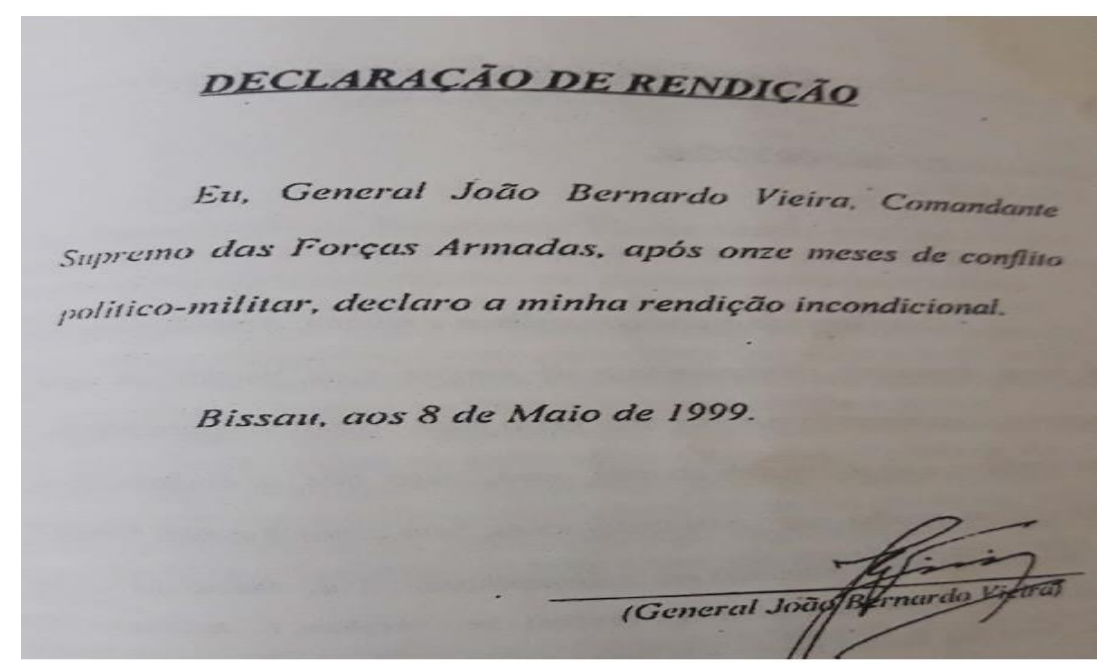

\section{Conclusão}

Ansumane Mané e João Bernardo vieira fizeram a guerra em Guiné-Bissau e foram vencedores. O povo não fez a guerra e perdeu a guerra.

Perdi tudo que amava e adorava. Que infância infeliz que eu tive e ainda hoje as crianças estão a ter essa mesma experiência que vivi.

Quem olhará para nossas crianças! 


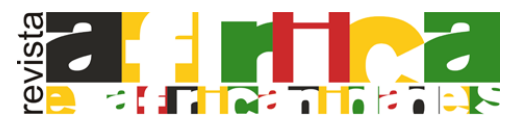

Revista África e Africanidades - Ano XIII - n. 34, maio. 2020 - ISSN 1983-2354 www. africaeafricanidades.com.br

\section{REFERÊNCIAS}

DISCO dancer. Direção: Babbar Subhash. Produção: Babbar Subhash. India: B. Subhash Movie Unit, 1982. 1 fita de vídeo (135 min), VHS, son., color.

INDUTA, Zamora. Guiné: 24 anos de independência 1974-1998. Hugin, 2001.

One war ends. The Economist, International. May 13th 1999 edition.

Disponível em: https://www.economist.com/international/1999/05/13/one-warends

Sete de Junho de 1998: "Esse conflito trouxe prejuízos aos guineenses", lamentam cidadãos. ANG - Agencia de Notícias da Guiné. Bissau, 7 jun. 2016. Disponível em: http://angnoticias.blogspot.com/2016/06/sete-de-junhode-1998.html 